Geochemical Journal, Vol. 1, pp 199 to. 210, 1967.

\title{
Sources of atmospheric sulfur compounds
}

\author{
Nobuyuki Nakai ${ }^{1}$ and Mead LeRoy Jensen ${ }^{2}$ \\ Department of Earth Sciences, Faculty of Science, Nagoya University, \\ Nagoya, Japan', and Laboratory of Isotope Geology, University of Utah, \\ Salt Lake City, Utah, U.S.A. ${ }^{2}$
}

(Received October 11, 1967; in revised form December 15, 1967)

\begin{abstract}
Sulfate samples from rain and snow water, collected in Japan and in U.S.A. have been studied isotopically in an attempt to determine the sources of atmospheric sulfur. $\delta^{34} \mathrm{~S}$ values of the samples are 5 to $18 \%$ lighter than that of sea water sulfate. Based on these isotopic data, it is suggested that the most important sources of atmospheric sulfate are hydrogen sulfide derived from bacterial reduction of sulfate and $\mathrm{SO}_{2}$ from industrial activities. Sea spray sulfate is a minor contributor.

In industrial sites, the sulfur in precipitation indicates depletion in ${ }^{34} \mathrm{~S}$, viz. +3.2 to $+7.3 \%$ in contrast to $\delta^{34} \mathrm{~S}$ values in non-industrial sites, that vary from +12.3 to $+19.0 \%$. It is suggested that the lighter isotopic composition of atmospheric sulfur may be explained by the contribution of light sulfur from sulfur bearing fuels through industrial burning.
\end{abstract}

\section{INTRODUCTION}

Sulfur is always found as a trace component in the atmosphere where it occurs in particles as $\mathrm{SO}_{4}^{\approx}$ and in gases as $\mathrm{SO}_{2}$ and $\mathrm{H}_{2} \mathrm{~S}$. It is also an important constituent of condensation nuclei. The presence of $\mathrm{SO}_{2}$ in polluted or industrial atmospheres is well known, whereas its quantitative data for non-polluted areas are inadequate. Researches on the origins of atmospheric sulfur have been reported by Eriksson (1960, 1963), Östlund (1959), Junge and Werby (1958), Junge (1960), and Jensen and NAKaI (1961).

The study of sulfate to chloride ratios in air and rain water samples collected in Japan by SugawARA et al. (1949) indicates that rain water near sea coasts has higher sulfate to chloride ratios than does sea water, and lower ratios than does air. From these results, they concluded that sea spray sulfate produces two different types of salt particles in the atmosphere; viz. one is of $\mathrm{CaSO}_{4} \cdot 2 \mathrm{H}_{2} \mathrm{O}$ and the other of $\mathrm{NaCl}$ and $\mathrm{MgCl}_{2}$, and the hygroscopic salt particles of the latter type form nuclei in oceanic and coastal rains and are returned rapidly to the sea, whereas the non-hygroscopic sulfate particles form comparatively stable aerosol to survive in the atmosphere and to be brought inland. On the other hand, Junge and WERBY (1958) indicated from studies of the ratios of sulfate to chloride in rain water from U.S.A. that over oceans sulfate of non-marine origin is a small fraction 
of the total sulfate present because sea water is logically the most important source, but over land sulfate of marine origin apparently decreases to negligible amount.

JUNGE and WERBY (1958) suggested the existence of sulfate sources other than sea water. Junge (1960) suggested that industrial $\mathrm{SO}_{2}$ is sufficient to account for the total amount of atmospheric sulfate over large continents.

Hydrogen sulfide is produced through bacterial reduction of sulfate and decomposition of organic materials by bacteria that are ubiquitous in ground and near shore sediments, and is oxidized to sulfate in the atmosphere. In this paper, following sources of the sulfate in the atmosphere are considered: 1) Industrial sulfur, 2) Bacteriogenic sulfur, 3) Sea spray sulfate, and 4) Volcanic sulfur. In order to determine the validity of those four suggested sources of atmospheric sulfur, we have attempted to apply sulfur isotopic studies to the problem of the sources of sulfate in precipitation.

\section{The Isotopic Distribution of Atmospheric Sulfur}

Initially, $\mathrm{SO}_{4}=$ samples of rain waters collected in Japan were selected because they should contain both industrial sulfur and oceanic $\mathrm{SO}_{4}^{-}$(Fig. 1). The analyses of such samples might provide a small scale example of how this type of study could be applied to a continent. In addition to the analyses of Japanese samples, rain water $\mathrm{SO}_{4}{ }^{3}$ and snow $\mathrm{SO}_{4}^{=}$samples in North America were analyzed isotopically.

The isotopic results of $\mathrm{SO}_{4}{ }^{7}$ in rain water obtained are listed in Tables 1 and

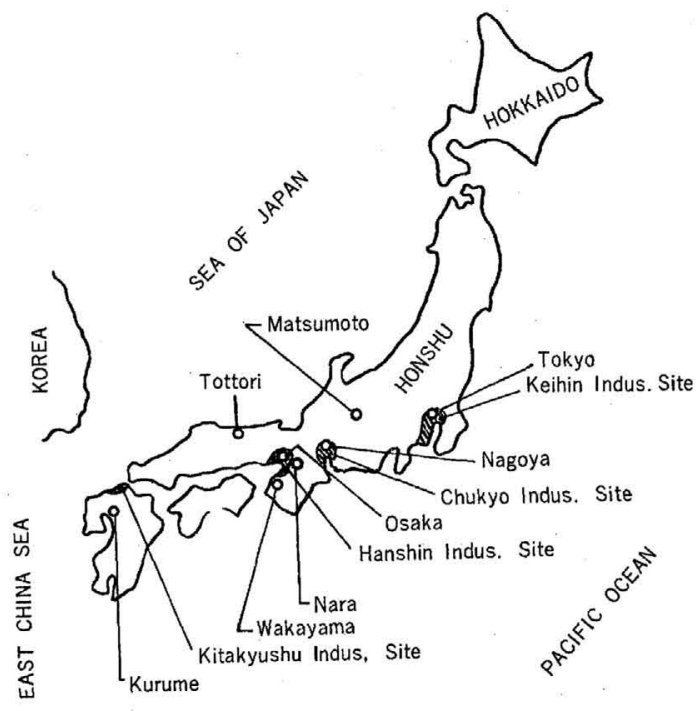

Fig. 1. The location map of rain and snow samples examined. 
2, and are plotted in Fig. 2 in comparison with similar measurements of sea water $\mathrm{SO}_{4}{ }^{*} *$

Table 1. Isotopic composition of sulfate in rain water and sea water from Japan supplied by E. KAMATA

\begin{tabular}{llcc}
\hline \hline Sample location & Sample & $\begin{array}{c}\text { Sulfate content } \\
(\mathrm{mg} \mathrm{S} / 1)\end{array}$ & $\begin{array}{c}\text { Isotopic composition } \\
\delta^{34} \mathrm{~S}(\% 0)\end{array}$ \\
\hline Tokyo (A)* & Rain & 3.0 & +7.3 \\
Tokyo (B)* & Rain & 2.9 & +7.3 \\
Tokyo (C)* & Rain & - & +5.0 \\
Nagoya (B)* & Rain & 0.77 & +5.9 \\
Nagoya (C)* & Rain & - & +3.2 \\
Wakayama** & Rain & 1.2 & +7.3 \\
Nara** & Rain & 0.43 & +6.3 \\
Kurume (A) & Rain & 1.0 & +15.6 \\
Kurume (B) & Rain & 0.70 & +12.8 \\
Kurume (C) & Rain & - & +15.6 \\
Tottori (A) & Snow & 0.90 & +13.2 \\
Tottori (B) & Rain & 0.77 & +15.1 \\
Matsumoto & Rain & - & +12.3 \\
East China Sea & Sea water & - & +20.7 \\
Wakayama & Sea water & - & +20.7 \\
\hline
\end{tabular}

* Industrial sites. $\quad$ ** Near industrial sites.

Table 2. Isotopic composition of sulfur in snow, rain and sea waters sampled in U.S.A.

\begin{tabular}{llcc}
\hline \multicolumn{1}{c}{ Sample location } & \multicolumn{1}{c}{ Sample } & $\begin{array}{c}\text { Sulfate content } \\
(\mathrm{mg} \mathrm{S} / 1)\end{array}$ & $\begin{array}{c}\text { Is otopic composition } \\
\delta^{34} \mathrm{~S}(\%)\end{array}$ \\
\hline New Haven, Conn. & Snow & 1.2 & +5.9 \\
& & 1.2 & +6.2 \\
Pittsfield, Mass. & Rain & 0.23 & +19.0 \\
& & 0.26 & +18.9 \\
Branford Bay No. 1, Conn. & $\begin{array}{l}\text { Sea water } \\
(4.5 \text { m depth })\end{array}$ & 666 & +20.3 \\
Branford Bay No. 2, Conn. & $\begin{array}{l}\text { Sea water } \\
(5.5 \text { m depth })\end{array}$ & 640 & +20.5 \\
Long Island Sound, Conn. & $\begin{array}{l}\text { Sea water } \\
(7.0 \text { m depth })\end{array}$ & 725 & +20.5 \\
Gulf of Mexico & $\begin{array}{l}\text { Sea water } \\
\text { (surface) }\end{array}$ & 881 & +20.6 \\
Gulf of Mexico & $\begin{array}{l}\text { Sea water } \\
(3,500 \text { m depth })\end{array}$ & 785 & +20.4 \\
\hline
\end{tabular}

* The mass analyses of samples are compared with troilite from Cañon Diablo meteorite as a standard with a ${ }^{34} \mathrm{~S} /{ }^{32} \mathrm{~S}$ ratio of 0.0450045 as follows:

$$
\delta^{34} \mathrm{~S}(\%)=\left[\frac{{ }^{34} \mathrm{~S} /{ }^{32} \mathrm{~S}(\text { sample })}{{ }^{34} \mathrm{~S} /{ }^{32} \mathrm{~S}(\text { std. })}-1\right] \times 1,000
$$




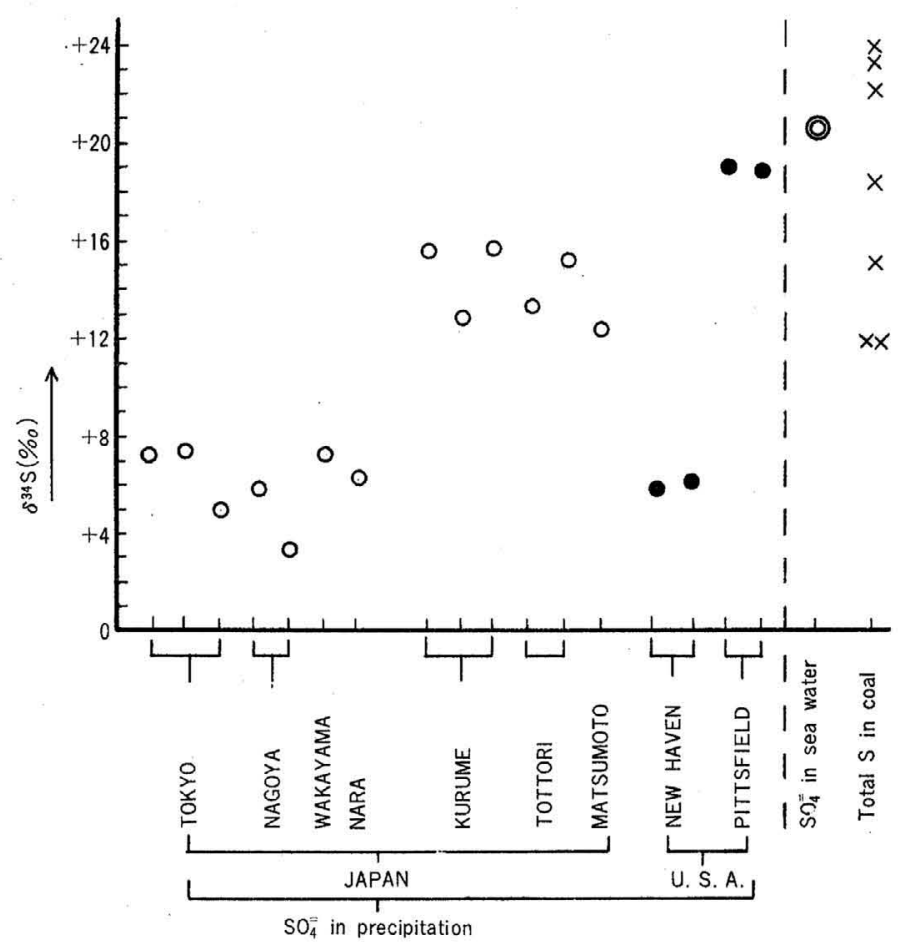

Fig. 2. Sulfur isotopes of sulfate in precipitation and sea water, and of sulfur in industrial coal.

Based on the sulfur isotopic compositional data of Japanese samples, two types of rain water are apparent, one includes $\delta^{34} \mathrm{~S}$ values ranging from +3.2 to $+7.3 \%$, the other between +12.3 and $+15.6 \%$. The former includes samples from or near industrial sites and the latter samples collected in non-industrial sites. Apparently ${ }^{34} \mathrm{~S}$ is depleted in the samples from industrial sites. The sulfur isotopic composition of sea water $\mathrm{SO}_{4}^{-}$, however, is remarkably constant at $+20.7 \%$, which is more enriched in ${ }^{34} \mathrm{~S}$ than either type of rain waters. The data of $\mathrm{SO}_{4}^{=}$for the rain and snow samples in North America not only correlate with the industrial type and non-industrial type of isotopic analyses in Japanese samples, but those of sea water samples also further demonstrate the constancy in $\delta^{34} \mathrm{~S}$ values of sea water sulfate.

\section{Discussion of Results}

Natural sources of atmospheric sulfur

All of the $\delta^{34} \mathrm{~S}$ results indicate that rain and snow $\mathrm{SO}_{4}{ }^{5}$ is depleted in ${ }^{34} \mathrm{~S}$ in comparison with the $\delta^{34} \mathrm{~S}$ value of sea water $\mathrm{SO}_{4}{ }^{2}$. Even if some of the rain water $\mathrm{SO}_{4}^{*}$ is originally marine, the results require additional sources of $\mathrm{SO}_{4}^{-}$that are 
depleted in "S. Various sources have already been suggested. Some $\mathrm{SO}_{4}^{=}$is formed in the atmosphere presumably by the oxidation of $\mathrm{SO}_{2}$ and $\mathrm{H}_{2} \mathrm{~S}$. This is based upon Junge's (1960) analyses which show that the total amount of $\mathrm{SO}_{2}$ and $\mathrm{H}_{2} \mathrm{~S}$ in the atmosphere is always about 1 to 2 orders of magnitude higher than the excess $\mathrm{SO}_{4}^{=}$( $\mathrm{SO}_{4}{ }^{7}$ of non-maritime origin) in aerosols. JunGE's measurements indicate that the variations in the $\mathrm{SO}_{2} / \mathrm{H}_{2} \mathrm{~S}$ ratio with time are due to changes in $\mathrm{SO}_{2}$ concentration, whereas the $\mathrm{H}_{2} \mathrm{~S}$ concentration is rather onstant. Furthermore, $\mathrm{H}_{2} \mathrm{~S}$ and $\mathrm{SO}_{2}$ concentrations determined by JACoBs et al. (1958) indicate that, even in New York City, where air is polluted primarily by industrial activities, the $\mathrm{H}_{2} \mathrm{~S}$ content of air is low and rather constant through the year.

It does seem apparent, therefore, that the $\mathrm{H}_{2} \mathrm{~S}$ is of natural bacterial origin, and $\mathrm{SO}_{2}$ is derived from human activities or produced by oxidation of $\mathrm{H}_{2} \mathrm{~S}$. The $\mathrm{SO}_{2}$ can be oxidized to $\mathrm{SO}_{3}$ by photochemical oxidation and catalitic oxidation, and $\mathrm{SO}_{3}$ is readily transferred to $\mathrm{H}_{2} \mathrm{SO}_{4}$ that dissolves in rain water.

Even though coastal samples may still contain $\mathrm{SO}_{4}^{=}$derived from sea spray, enrichment of ${ }^{32} \mathrm{~S}$ in them does suggest that $\mathrm{H}_{2} \mathrm{~S}$ formed by bacterial reduction of sulfate in tidal flats and coastal belts may be an important source of sulfur in the atmosphere (NAKaI and JENSEN, 1964). Data on the isotopic compositions of sulfide produced presumably by the biochemical reduction of sulfate in bottom sediments, are listed in Table 3 for both marine and fresh water samples. Such sulfides exhibit $\delta^{34} \mathrm{~S}$ values lighter than the co-existing sulfate; the $\delta^{34} \mathrm{~S}$ values of sulfides range approximately from -10 to $-20 \%$ for marine samples and from -3.5 to $+1.6 \%$

Table 3. Sulfur isotopes of sulfate in sea and lake waters, and of sulfide in sediments

\begin{tabular}{|c|c|c|c|c|}
\hline Sample location & $\underset{\text { (m) }}{\text { Depth }}$ & $\begin{array}{c}\mathrm{SO}_{4}^{=} \text {in water* } \\
\text { content } \\
(\mathrm{mg} \mathrm{S} / 1)\end{array}$ & $\begin{array}{l}\delta^{34} \mathrm{~S} \\
(\% 0)\end{array}$ & $\begin{array}{c}\text { Acid soluble } \\
\text { sulfide in sediments } \\
\delta^{34} \mathrm{~S} \\
\left(\%_{0}\right)\end{array}$ \\
\hline \multicolumn{5}{|l|}{ Sea } \\
\hline Long Island Sound, & 7.0 & 725 & +20.5 & -12.2 \\
\hline Conn., U.S.A. & 7.0 & 722 & +20.5 & -12.9 \\
\hline Branford Bay, Conn., & 4.5 & 666 & +20.3 & -21.8 \\
\hline U.S.A. & 3.5 & 640 & +20.5 & -20.8 \\
\hline \multicolumn{5}{|l|}{ Lake } \\
\hline Linsley Pond, Conn., & 13.0 & - & +9.5 & +1.6 \\
\hline U.S.A. & 13.0 & 4.3 & +7.7 & -3.5 \\
\hline $\begin{array}{l}\text { Queechy Lake, Conn., } \\
\text { U.S.A. }\end{array}$ & 12.0 & 4.6 & +5.8 & +0.4 \\
\hline $\begin{array}{l}\text { Mt. Tom Pond, Conn., } \\
\text { U.S.A. }\end{array}$ & 13.5 & 5.1 & +6.1 & -3.0 \\
\hline
\end{tabular}

* Sampled from deep water layers. 
for fresh water samples, and the isotopic fractionation factors between sulfate and co-existing sulfide $\left(\frac{{ }^{34} \mathrm{~S} /{ }^{32} \mathrm{~S}\left(\mathrm{SO}_{4}^{2}\right)}{{ }^{34} \mathrm{~S} /{ }^{32} \mathrm{~S}\left(\mathrm{H}_{2} \mathrm{~S}\right)}\right)$ are 1.033 to 1.043 and 1.005 to 1.011 , respectively.

Based on laboratory fermentation experiments using pure culture cells, THODE et al. (1951) and JoNES and STARKEY (1957) have obtained the isotopic fractionation factors between sulfate and produced sulfide varying from 1.003 to 1.018. NAKAI and JENSEN (1960) have obtained values varying from 1.005 to 1.017 , using raw culture techniques. Recently, however, NAKAI and Jensen (1964) revealed that the bacterial reduction of $\mathrm{SO}_{4}^{=}$to $\mathrm{H}_{2} \mathrm{~S}$, in unidirectional reactions with a limited $\mathrm{SO}_{4}^{=}$ supply in a closed system, brings forth fractionation factors that can be calculated by the following equation:

$$
\begin{gathered}
r=\frac{R_{\mathrm{SO}_{4}}=\frac{1-F}{R_{\mathrm{S}}=}}{F^{1-\left(K_{2} / K_{1}\right)}-F} \\
F=\text { fraction of the initial } \mathrm{SO}_{4}^{=} \text {remaining; } F \text { is } 1 \text { at the start } \\
\text { of the reaction and approaches } 0 \text { as reaction progresses. } \\
R_{\mathrm{S}}=\text { and } R_{\mathrm{SO}_{4}=}={ }^{34} \mathrm{~S} /{ }^{22} \mathrm{~S} \text { ratio of produced } \mathrm{S}=\text { and residual } \mathrm{SO}_{4}^{=} . \\
\text {at } F \text {, respectively. } \\
K_{1} \text { and } K_{2}=\text { the rate constants in the redution for light and } \\
\text { heavy isotopes, respectively. }
\end{gathered}
$$

We found that the $K_{1} / K_{2}$ ratio in the above equation averages 1.020 , indicating that ${ }^{32} \mathrm{~S}$ is reduced to $\mathrm{H}_{2} \mathrm{~S}$ two percent faster than ${ }^{34} \mathrm{~S}$. $F$ values should be less than unity. Consequently, the next relation can be introduced, i.e.,

$$
F^{\mathrm{i}-\left(K_{\mathrm{z}} / K_{1}\right)}-F<1-F \text {. }
$$

Therfore, for $R_{\mathrm{S}}=$ and $R_{\mathrm{SO}_{4}}{ }^{*}$ :

$$
r=\frac{R_{\mathrm{SO}_{\mathrm{4}}}=}{R_{\mathrm{S}}=}>1
$$

This indicates that the isotopic composition of $\mathrm{H}_{2} \mathrm{~S}$ produced is always enriched in ${ }^{32} \mathrm{~S}$ in comparison with the original $\mathrm{SO}_{4}^{-*}$.

In the case of an unlimited supply of $\mathrm{SO}_{4}{ }^{2}$ in an open system the following relation is derived by using the $K_{1} / K_{2}$ value of 1.020 .

$$
r=\frac{R_{\mathrm{SO}_{4}}{ }^{-}}{R_{\mathrm{S}}=}=1.020 \text {. }
$$

So, if $\mathrm{H}_{2} \mathrm{~S}$ is produced in an open system and released to atmosphere, its isotopic composition should be $20 \%$ lighter than that of original $\mathrm{SO}_{4}^{=}$.

The most important source of $\mathrm{SO}_{4}^{-}$, from which $\mathrm{H}_{2} \mathrm{~S}$ is produced by bacterial reduction, is presumably pore water of near shore sediments, but the amount of $\mathrm{H}_{2} \mathrm{~S}$ being produced from swamps, sewage disposal areas and sluggish streams is still 
Table 4. Sulfur isotopes of volcanic gases (determined by OANA and SAKAI)

\begin{tabular}{cllllll}
\hline Fumarole & $\begin{array}{c}\text { Temp. } \\
\left({ }^{\circ} \mathrm{C}\right)\end{array}$ & $\left(1 / \mathrm{m}^{3}\right)$ & $\delta^{34} \mathrm{~S}\left(\%_{0}\right)$ & $\left(1 / \mathrm{m}^{3}\right)$ & $\mathrm{SO}_{2} \delta^{34} \mathrm{~S}(\%)$ & $\begin{array}{c}\text { TotalS } \\
\delta^{34} \mathrm{~S}\left(\%_{0}\right)\end{array}$ \\
\hline Showashinzan & & & & & & \\
A-1 & 722 & 0.008 & - & 0.14 & +4.4 & +4.4 \\
A-6 & 695 & 0.009 & - & 0.10 & +5.5 & +5.5 \\
B-1b & 260 & 0.10 & +5.5 & 0.003 & +13.9 & +5.7 \\
B-5 & 446 & 0.11 & +4.4 & 0.004 & +9.3 & +4.6 \\
B-6 & 347 & 0.12 & +4.3 & 0.004 & +9.2 & +4.5 \\
C-2 & 605 & 0.079 & +5.1 & 0.047 & +7.1 & +6.0 \\
C-3 & 187 & 0.17 & +1.7 & 0.002 & +10.0 & +1.8 \\
Nasu & & & & & & \\
M-1 & 489 & 3.2 & -0.7 & 3.4 & +4.4 & +1.9 \\
M-2 & 195 & 5.9 & -0.9 & 0.36 & +6.1 & -0.5 \\
M-2b & 352 & 3.5 & -1.2 & 0.88 & +10.1 & +1.1 \\
\hline
\end{tabular}

* Weighted mean of $\mathrm{SO}_{2}$ and $\mathrm{H}_{2} \mathrm{~S}$.

unknown. Furthermore, lakes can also be a source of $\mathrm{H}_{2} \mathrm{~S}$. ERIKsson (1963) has stressed that an appreciable amount of sulfur is supplied as $\mathrm{H}_{2} \mathrm{~S}$ from oceans into the atmosphere. ÖstLund and Alexander (1963), however, reported that a layer of only a few feet of oxygenated sea water may prevent the escape of $\mathrm{H}_{2} \mathrm{~S}$ generated in the underlying mud.

Even though volcanism is a minor source for rain water $\mathrm{SO}_{4}{ }^{-}$as estimated by Koyama et al. (1965), volcanic gases do add sulfur ccompounds to the atmosphere. Sulfur compounds in volcanic gases are predominantly $\mathrm{SO}_{2}$ and $\mathrm{H}_{2} \mathrm{~S}$, and the ratios of them vary with fumarolic temperatures. SAKAI and NAGASAWA (1958) have studied quantitatively and isotopically the sulfur compounds in volcanic gases. Recently, OANA and SAKaI studied the sulfur compounds from Volcano Showashinzan and Nasu in detail. Some of their results are presented in Table 4. The $\mathrm{SO}_{2} / \mathrm{H}_{2} \mathrm{~S}$ ratios and the fractionation factors between $\mathrm{SO}_{2}$ and $\mathrm{H}_{2} \mathrm{~S}$ differ with varying fumarolic temperatures. The isotopic compositions of total sulfur, weighted mean $\delta^{34} \mathrm{~S}$ of $\mathrm{SO}_{2}$ and $\mathrm{H}_{2} \mathrm{~S}$, however, are comparatively constant for all fumaroles, viz. from -0.5 to +6.9 $\%$. The $\delta^{34} \mathrm{~S}$ values of volcanic gases, therefore, are enriched in ${ }^{32} \mathrm{~S}$ in comparison with sea water sulfate.

All of the natural sources of rain water $\mathrm{SO}_{4}^{=}$examined above have $\delta^{34} \mathrm{~S}$ values lighter than sea water sulfate.

\section{Anthropogenic sources of atmospheric sulfur}

According to JUNGE and WERBY (1958), the amount of sulfur emitted into the air by human activities was $1.2 \times 10^{8}$ tons for the whole earth in 1956 . This presents only one-third of the total amount of excess $\mathrm{SO}_{4}^{-}$brought down by precipitation. 
Table 5. Isotopic composition of sulfur in industrial coals in Japan

\begin{tabular}{lcc}
\hline \multicolumn{1}{c}{ Coal Mine } & $\begin{array}{c}\text { Total sulfur content* } \\
(\%)\end{array}$ & $\begin{array}{c}\text { Isotopic composition } \\
\delta^{3} \text { S }(\%)\end{array}$ \\
\hline Kyushu No. 1 & 1.54 & +23.5 \\
Kyushu No. 1' & 1.44 & +23.9 \\
Kyushu No. 2 & 3.05 & +11.9 \\
Kyushu No. 2' & 3.14 & +11.9 \\
Kyushu No. 3 & 1.49 & +22.1 \\
Hokkaido No. 1 & 0.33 & +18.3 \\
Hokkaido No. 2 & 0.35 & +15.1 \\
\hline
\end{tabular}

* Determined by Parr Bomb method.

Koyama et al. (1965) estimated that in Japan the amounts of $\mathrm{SO}_{4}^{=}$from sources except sea spray, fuel and volcanoes are $6.5 \times 10^{6}$ tons, and correspond to $75 \%$ of the total fallout of $\mathrm{SO}_{4}^{=}, 8.7 \times 10^{6}$ tons, and sulfur emitted by fuel is only $1.8 \times 10^{6}$ tons as $\mathrm{SO}_{4}^{-}$in 1959 . Our isotopic results, however, indicate that rain water $\mathrm{SO}_{4}^{-}$collected from industrial sites are significantly more enriched in ${ }^{32} \mathrm{~S}$ than are samples from non-industrial sites. Therefore, it is inferred that these samples from industrial sites contain $\mathrm{SO}_{4}^{-}$derived predominantly from atmospheric oxidation of isotopically light $\mathrm{SO}_{2}$ emitted by industrial activities.

If the $\delta^{34} \mathrm{~S}$ composition of industrial fuels could be determined, the amount of industrial sulfur in the precipitation samples would possibly be estimated. For this purpose, five coal samples were obtained from two of the most productive Japanese

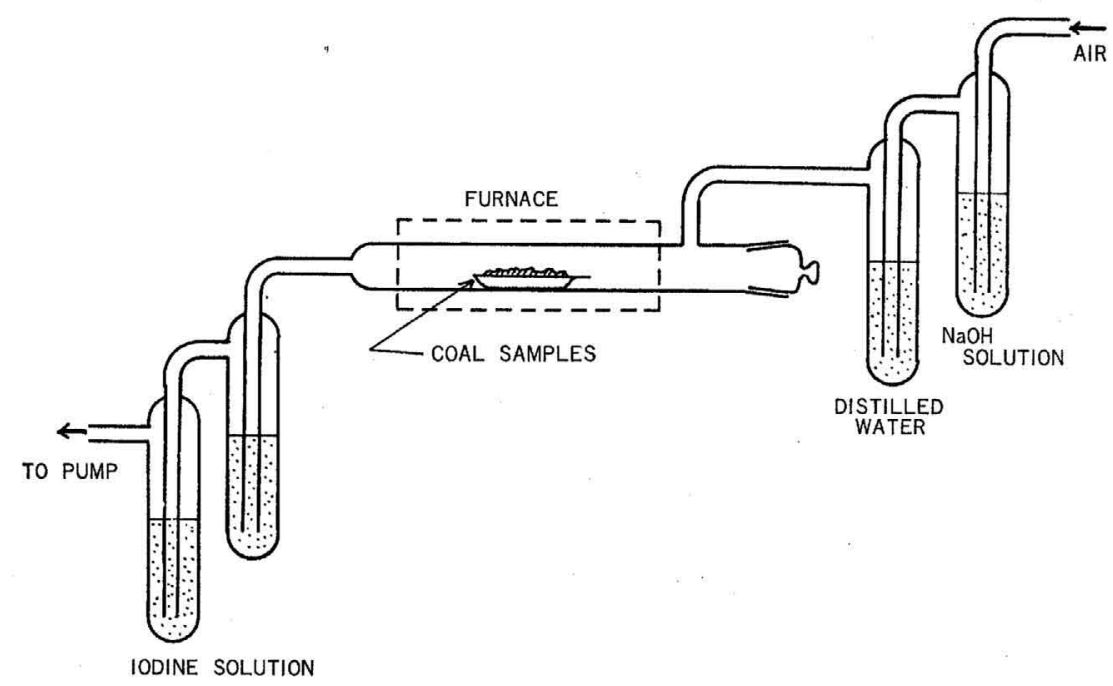

Fig. 3. Apparațus for çoal burning experimenț. 
Table 6. Results of burning experiments of coal in the laboratory

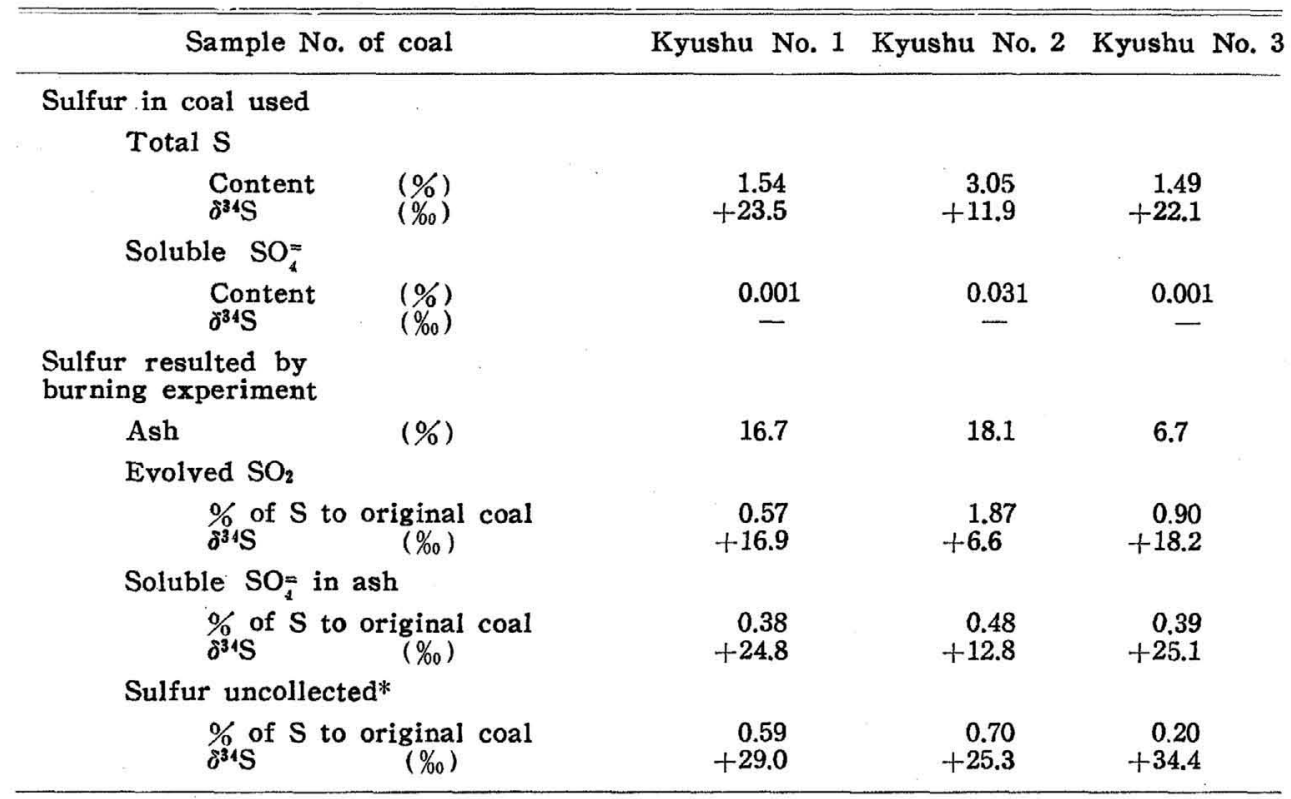

* Calculated values.

coal mines. The isotopic composition of the total sulfur in the samples are presented in Table 5 and Fig. 2. Unfortunately, the relatively broad spread in their isotopic compositions, from +11.9 to $+23.5 \%$ in $\delta^{34} \mathrm{~S}$ values, presents a difficulty in explaining the enrichment of ${ }^{32} \mathrm{~S}$ in atmospheric $\mathrm{SO}_{4}^{*}$ samples collected near industrial sites, all of which have $\delta^{3} 4 \mathrm{~S}$ compositions lighter than $+7.3 \%$.

Isotopic fractionation, however, might be expected in the process of coal burning. In order to test such, laboratory burning experiments were performed on Kyushu coal samples Nos. 1,2 and 3. The apparatus used is shown in Fig. 3. Coal samples of 2 to $3 \mathrm{~g}$ were placed in a combustion tube. A constant stream of air, which was purified by bubbling through $1 \mathrm{~N} \mathrm{NaOH}$ solution, was passed through the system with the coal samples heated. The resulting $\mathrm{SO}_{2}$ was oxidized to $\mathrm{SO}_{4}^{\overrightarrow{ }}$ by iodine solution, precipitated as $\mathrm{BaSO}_{4}$, converted to silver sulfide, burned to $\mathrm{SO}_{2}$, and analyzed isotopically. The sulfate remained in the ash was leached with distilled water, precipitated as $\mathrm{BaSO}_{4}$, and analyzed isotopically. These experimental results are shown in Table 6 and Fig. 4.

The analytical and isotopic results indicate that the water soluble $\mathrm{SO}_{4}^{=}$in the ash is produced during the burning process of coal, because the amount of soluble $\mathrm{SO}_{4}^{-}$remaining in ash is always 1 to 2 orders of magnitude higher than in the original coal. Quantitative and isotopic analyses indicate that 37 to $61 \%$ of the original sulfur contained in the coal samples produced $\mathrm{SO}_{2}$ gas and 16 to $26 \%$ 


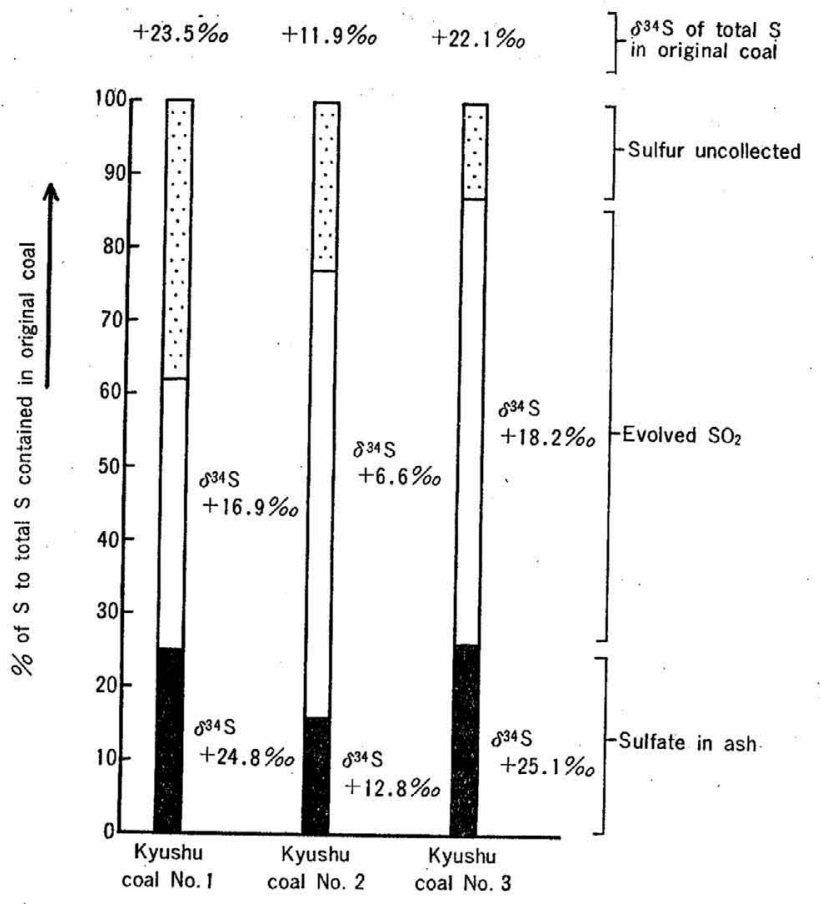

Fig. 4. Sulfur isotopic fractionation in coal-burning experiments.

remained in the ash as sulfate, and that the $\mathrm{SO}_{2}$ gas produced was always enriched in ${ }^{32} \mathrm{~S}$, while the soluble sulfate in the ash was enriched in ${ }^{34} \mathrm{~S}$ in reference to the total sulfur of the original coal samples. The sulfur in the amount of 10 to $40 \%$ of original sulfur could not be collected during the burning experiment, and is supposed to have been converted to $\mathrm{SO}_{3}$ and fixed in the experimental system. The $\delta^{34} \mathrm{~S}$ values expected for this sulfur can be calculated to be +25 to $+35 \%$ as shown in Table 6. It is evident that the lighter isotope goes predominantly to $\mathrm{SO}_{2}$. The difference in $\delta^{34} \mathrm{~S}$ between the $\mathrm{SO}_{2}$ produced and the total sulfur contained in the coal samples is still not large enough to explain the comparatively light isotopic composition of atmospheric sulfur from industrial sites.

It is expected, however, that during the process of coal burning and transportation of fume to the atmosphere through the exhaust path of stacks longer than that of the laboratory burning apparatus, the $\mathrm{SO}_{2}$ reacts with oxygen in air to produce more $\mathrm{SO}_{3}$ than in the burning experiment. The isotopic fractionation factors between $\mathrm{SO}_{2}$ and $\mathrm{SO}_{3}\left(\left[{ }^{34} \mathrm{SO}_{3} /{ }^{32} \mathrm{SO}_{3}\right] /\left[{ }^{34} \mathrm{SO}_{2} /{ }^{32} \mathrm{SO}_{2}\right]\right)$ increase with lowering temperature as shown in Table 7.

Koyama et al. (1965) estimated the coal and oil consumption in 1959 to be 5.5 $\times 10^{7}$ and $2.3 \times 10^{7}$ tons respectively in Japan, and then from the following data calculated the $\delta^{34} \mathrm{~S}$ values of total fuels to be $+9.4 \%$; average sulfur contents $=$ 
Table 7. Equilibrium constants for exchange reaction between $\mathrm{SO}_{3}$ and $\mathrm{SO}_{2}$ (SAKAI, 1957)

\begin{tabular}{cccccc}
\hline \hline Temperature $\left({ }^{\circ} \mathrm{C}\right)$ & 25 & 50 & 100 & 500 & 1,000 \\
\hline$\left(\frac{{ }^{34} \mathrm{SO}_{3}^{3}}{{ }^{32} \mathrm{SO}_{3}^{-}}\right) /\left(\frac{{ }^{34} \mathrm{SO}_{2}}{{ }^{32} \mathrm{SO}_{2}}\right)$ & 1.020 & 1.016 & 1.015 & 1.003 & 1.003 \\
\hline
\end{tabular}

0.35 and $1.76 \%, \delta^{3} 4 \mathrm{~S}$ values $=+19.6$ and $+4.6 \%$ for coal and oil, respectively. If the $\delta^{3} \mathrm{~S}$ value of $+9.4 \%$ is accepted as that of the total fuel, and sulfur isotopic fractionation in the burning process of oil is assumed to be similar to that of coal, the difference in $\delta^{34} \mathrm{~S}$ between the $\mathrm{SO}_{2}$ produced in the burning experiments and the original sulfur can enough explain the light isotopic composition of atmospheric sulfur from industrial sites.

Further investigations are necessary to be able to explain fully the sources of atmospheric sulfur. But we suggest that an application of sulfur iotope chemistry to studies on the origin of atmospheric sulfur is a prime method by which further knowledge may be obtained.

\section{ACKNowledgements}

We acknowledge the kind assistance of Drs. K. Sugawara and E. Kamata who supplied the precipitation sulfate samples that were collected in Japan. The laboratory research for this study was done under support of A. E. C. Contract AT $(30-1)$ and N. S. F. Grant 14283.

\section{REFERENCES}

ERIKSSON, E. (1960) The yearly circulation of chloride and sulfur in nature. Tellus 12, 63109.

ERIKSON, E. (1963) The yearly circulation of sulfur in nature. J. Geophys. Res. 68, 4001-4008.

JACOBS, M. B., BAVERMAN, M. N. and HOCHHEISER, S. (1958) Ultramicro determination of sulfides in air. Anal. Chem. 29, 1449-1351.

JENSEN, M. L. and NAKAI, N. (1961) Sources and isotopic composition of atmospheric sulfur. Science 134, 2102-2104.

JONES, G. and STARKEY, R. L. (1957) Fractionation of stable isotopes of sulfur by microorganisms and the role in deposition of native sulfur. Applied Microbiology 5, 111-118.

JUNGE, C. E. (1960) Sulfur in the atmosphere. J. Geophys. Res. 65, 227-237.

JUNGE, C. E. and WERBY, R. T. (1958) The concentration of chloride, sodium, potassium, calcium, and sulfate. J. Meteorol. 15, 417-425.

Koyama, T., NAKAI, N. and Kamata, E. (1965) Possible discharge rate of hydrogen sulfide from polluted coastal belts in Japan. J. Earth Sci. Nagoya Univ. 13, 1-11.

NAKAI, N. and JENSEN, M. L. (1960) Biogeochemistry of sulfur isotopes. J. Earth Sci. Nagoya Univ. 8, 181-196.

NAKAI, N. and JENSEN, M. L. (1964) The kinetic isotope effect in the bacterial reduction and oxidation of sulfur. Geochim. Cosmochim. Acta 28, 1893-1912. 
ÖSTLUND, G. (1959) Isotopic composition of sulfur in precipitation and sea water. Tellus 11, 478-480.

ÖstLund, G. and ALEXANDER, J. (1963) Oxidation rate of sulfide in sea water, preliminary study. J. Geophs. Res. 68, 3995-3997.

SAKAI, H. (1957) Fractionation of sulfur isotopes in nature. Geochim. Cosmochim. Acta 12, 150-169.

SAKAI, H. and NAGASAWA, H. (1958) Fractionation of sulfur isotopes in volcanic gases. ibid. 15, $32-39$.

SugawarA, K., OANA, S. and KoYAMA, T. (1949) Separation of the components of atmospheric salt and their distribution. Bull. Chem. Soc. Japan 22, 47-52.

THODE, H., KLEEREKOPER, H. and MCELCHERAN, D. (1951) Isotope fractionation in the bacterial reduction of sulfate. Research $4,581-582$. 